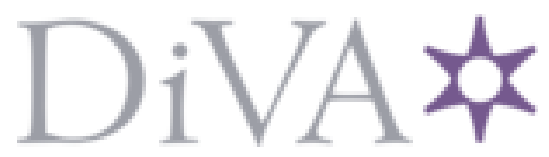

http://www.diva-portal.org

\title{
Preprint
}

This is the submitted version of a paper published in Journal of Power Sources.

Citation for the original published paper (version of record):

Liu, J., Wang, Z., Zhu, J. (2016)

Binder-free nitrogen-doped carbon paper electrodes derived from polypyrrole/cellulose composite for $\mathrm{Li}-\mathrm{O}_{2}$ batteries.

Journal of Power Sources, 306: 559-566

http://dx.doi.org/10.1016/j.jpowsour.2015.12.074

Access to the published version may require subscription.

N.B. When citing this work, cite the original published paper.

Permanent link to this version:

http://urn.kb.se/resolve?urn=urn:nbn:se:uu:diva-259587 


\title{
Binder-free nitrogen-doped carbon paper electrodes derived from
}

\section{polypyrrole/cellulose composite for $\mathrm{Li}-\mathrm{O}_{2}$ batteries}

Jia Liu, Zhaohui Wang, Reza Younesi, Leif Nyholm, Kristina Edström, and Jiefang Zhu*

Department of Chemistry - Ångström Laboratory, Uppsala University, Box 538, SE-751 21

Uppsala, Sweden

Tel.: +4618 471 3722, Fax: +46 18513548, E-mail: jiefang.zhu@kemi.uu.se

\begin{abstract}
This work presents a novel binder-free nitrogen-doped carbon paper electrode (NCPE), which was derived from a N-rich polypyrrole (PPy)/cellulose-chopped carbon filaments (CCFs) composite, for $\mathrm{Li}_{-} \mathrm{O}_{2}$ batteries. The fabrication of NCPE involved cheap raw materials (e.g., Cladophora sp. green algae) and easy operation (e.g., doping $\mathrm{N}$ by a carbonization of $\mathrm{N}$-rich polymer), which is especially suitable for large-scale production. Asprepared NCPEs were characterized by XRD, Raman, SEM, XPS, Brunauer-Emmett-Teller (BET), and thermogravimetry (TG) measurements. The NCPE exhibited a bird's nest microstructure, which could provide the self-standing electrode with considerable mechanic durability, fast $\mathrm{Li}^{+}$and $\mathrm{O}_{2}$ diffusion, and enough space for the discharge product deposition. In addition, the NCPE contained N-containing function groups, which may promote the electrochemical reactions. Furthermore, binder-free architecture designs can prevent binderinvolved parasitic reactions. A $\mathrm{Li}_{-} \mathrm{O}_{2}$ cell with the NCPE dispalyed a cyclability of more than 30 cycles at a constant current density of $0.1 \mathrm{~mA} / \mathrm{cm}^{2}$. The $1^{\text {st }}$ discharge capacity for a cell with the NCPE reached $8040 \mathrm{mAh} \cdot \mathrm{g}^{-1}$ at a current density of $0.1 \mathrm{~mA} / \mathrm{cm}^{2}$, with a cell voltage around $2.81 \mathrm{~V}$. In addition, a cell with the NCPE displayed a coulombic efficiency of $81 \%$ on the $1^{\text {st }}$ cycle at a current density of $0.2 \mathrm{~mA} / \mathrm{cm}^{2}$. These results represent a promising progress in the development of a low-cost and versatile paper-based $\mathrm{O}_{2}$ electrode for $\mathrm{Li}^{-} \mathrm{O}_{2}$ batteries.
\end{abstract}

Keywords: nitrogen-doped carbon paper electrode, binder-free, $\mathrm{Li}^{-} \mathrm{O}_{2}$ battery, bird's nest microstructure, $\mathrm{N}$-containing functional group. 


\section{Introduction}

The rechargeable $\mathrm{Li}-\mathrm{O}_{2}$ battery has recently attracted a great deal of attention because of its significantly higher theoretical energy density than traditional lithium-ion battery [1-5]. A Li$\mathrm{O}_{2}$ battery prototype is composed of a lithium metal anode, $\mathrm{Li}^{+}$-containing nonaqueous electrolyte, and a porous $\mathrm{O}_{2}$ cathode (normally carbon-based materials with or without catalysts). The key electrochemical reaction in a Li- $\mathrm{O}_{2}$ battery is $2 \mathrm{Li}+\mathrm{O}_{2} \rightleftarrows \mathrm{Li}_{2} \mathrm{O}_{2}$, with a discharge process (oxygen reduction reaction (ORR)) and a charge process (oxygen evolution reaction (OER)) [6,7]. Although $\mathrm{Li}^{-} \mathrm{O}_{2}$ batteries exhibit a great potential and much progress has been made, the main issues to be addressed are: 1) How to find a long-term stable electrolyte with high $\mathrm{O}_{2}$ solubility and diffusion; 2) How to design a stable $\mathrm{O}_{2}$ electrode with excellent electrocatalysts; 3) How to prevent the dendrite formation on the Li metal surface; 4) How to protect the electrodes from $\mathrm{CO}_{2}$ and $\mathrm{H}_{2} \mathrm{O}$.

The energy storage capacity, rate capacity, and cycle life are strongly determined by the materials and architecture of the $\mathrm{O}_{2}$ electrode [8]. Carbonaceous materials have been employed as fillers to provide the cathode with porosity and electronic conductivity [9]. It has been well established that a good carbon candidate for $\mathrm{Li}_{-} \mathrm{O}_{2}$ batteries should have characteristics as follows: i) appropriate pore size/volume; ii) large surface area, and iii) high stability. So far, various carbon materials have been systematically studied for $\mathrm{Li}_{-} \mathrm{O}_{2}$ batteries, such as commercial carbon powders [10], one-dimensional carbon nanomaterials [11], twodimensional graphene [12], mesoporous carbon materials [13], and carbon hybrids and composites [14-16]. To promote the electrochemical performance, the incorporation of heteroatoms in a well-defined way is regarded as a feasible strategy to modify the nature and chemical properties of pure carbon [9]. Among those heteroelements, nitrogen (N), having a comparable atomic size to carbon and five valence electrons for bonding with the carbon atom, has been widely adopted $[17,18]$. $\mathrm{N}$-doped carbon can not only improve the $\mathrm{Li}^{+}$ diffusion and transfer by generating defects and by withdrawing electrons from the carbon atom, but also increase the conductivity of the resulting carbon, which can exhibit a better battery performance than pure carbon materials [19-22]. Many approaches have been reported for the synthesis of $\mathrm{N}$-doped carbon [22-24]. Those synthetic routes normally require multiple or complicate steps, with low yield and high cost, which inevitably limit large-scale fabrication. Therefore, to obtain high-performance $\mathrm{N}$-doped carbon by an easy-to-operate and low-cost method is really a challenge.

Besides the stability of electrolyte, the composition and architecture of the $\mathrm{O}_{2}$ electrode also influences the performance of $\mathrm{Li}_{-} \mathrm{O}_{2}$ batteries. Typically, a $\mathrm{N}$-doped carbon-based electrode consists of $\mathrm{N}$-doped carbon powder, polymer binder, and catalyst. The multiple components complicate the cell preparation and the electrochemical reactions, and also impose the challenges on the analysis. In addition, carbon particles in an electrode using chemical binder sometimes display a tight aggregation, which inevitably decreases the $\mathrm{O}_{2}$ diffusion and limits the space for $\mathrm{Li}_{2} \mathrm{O}_{2}$ deposition. This consequently leads to a limited capacity and a low energy efficiency of the $\mathrm{Li}^{-} \mathrm{O}_{2}$ battery [25]. Moreover, the binder degradation can clog the $\mathrm{O}_{2}$ electrode surface and then reduce the space for the desired discharge product $\mathrm{Li}_{2} \mathrm{O}_{2}[7,26]$. Binder-free $\mathrm{O}_{2}$ electrode, designed to avoid the negative influence of the binder, has been reported and recognized as an appealing alternative for Li$\mathrm{O}_{2}$ batteries [18, 25, 27-29]. We have developed a straightforward approach to the manufacture of sustainable paper electrodes based on a high-porous polypyrrole (PPy)/Cladophora cellulose composite, and thus the possibility to use the carbonized derivative as binder-free electrodes for $\mathrm{Li}-\mathrm{O}_{2}$ batteries is highly appealing [30-33]

Herein, we report a novel design of a binder-free N-doped carbon paper electrode (NCPE) in the $\mathrm{Li}-\mathrm{O}_{2}$ battery derived from a N-rich PPy/cellulose-chopped carbon filaments (CCFs) composite. The synthetic strategy combines the low-cost and easily accessible raw materials, and a facile operation. The NCPE displays a bird's nest microstructure, which can provide the 
electrode with considerable mechanic durability, fast $\mathrm{Li}^{+}$and $\mathrm{O}_{2}$ diffusion, and enough space for the discharge product deposition. The rate performance, coulombic efficiency, and cyclability of the $\mathrm{Li}_{-} \mathrm{O}_{2}$ batteries with NCPEs were investigated. The function of the NCPEs is related to their $\mathrm{N}$-containing function groups and self-standing bird's nest microstructure. We expect that this new designed $\mathrm{NCPE}$ can be manufactured and used as an electrode material for broad applications (e.g., Li-ion batteries, fuel cells, supercapacitors, etc.).

\section{Experimental}

\subsection{Materials}

All chemicals were of analytic grade and used as received without any further purification. Cladophora green algae was collected from the Baltic Sea, and the Cladophora nanocellulose was extracted from the algae by grinding and acid hydrolysis as previously described [34]. Iron (III) chloride nonahydrate $\left(\mathrm{FeCl}_{3} \cdot 6 \mathrm{H}_{2} \mathrm{O}\right)$, hydrochloric acid $(\mathrm{HCl})$ and pyrrole (Py) were purchased and used as delivered from Sigma-Aldrich. The carbon filaments (CFs) were obtained from Goodfellow, UK. The CFs were simply chopped with a kitchen herb-cutter knife on a wooden block so as to obtain a fluffy mass consisting of individual CCFs with a maximum length of $5 \mathrm{~mm}$. $1 \mathrm{M}$ lithium perchlorate $\left(\mathrm{LiClO}_{4}, \mathrm{GFS}, \geq 99 \%\right)$ in dimethyl sulfoxide (DMSO, Aldrich, $\geq 99.9 \%$ ) was prepared as electrolyte in the $\mathrm{Li}^{-} \mathrm{O}_{2}$ battery.

\subsection{Preparation of the NCPE}

Cladophora cellulose $(200 \mathrm{mg})$ was dispersed in water $(40 \mathrm{~mL})$ by sonication for 10 min with water cooling. The sonication was carried out with a high-energy ultrasonic equipment (Sonics and Materials Inc., USA, Vibra-Cell 750) at an amplitude of $30 \%$ with a pulse length of $30 \mathrm{~s}$ and pulse-off duration of $30 \mathrm{~s}$. Pyrrole $(0.65 \mathrm{~mL})$ and $0.5 \mathrm{M} \mathrm{HCl}(40 \mathrm{~mL})$ were mixed with the cellulose dispersion by magnetic stirring for $5 \mathrm{~min}$. PPy was then formed on the Cladophora cellulose fibers via polymerization with $\mathrm{FeCl}_{3} \cdot 6 \mathrm{H}_{2} \mathrm{O}(5.9 \mathrm{~g})$ dissolved in $0.5 \mathrm{M}$ $\mathrm{HCl}(40 \mathrm{~mL})$ as an oxidant. The polymerization proceeded for 30 min under stirring, after which the composite was collected in an Büchner funnel connected to a suction flask, and washed with $0.5 \mathrm{M} \mathrm{HCl}(3 \mathrm{~L})$ and $0.1 \mathrm{M} \mathrm{HCl}(0.5 \mathrm{~L})$. The PPy/cellulose composite precursor has been extensively characterized in our previous work [30-32]. The PPy/cellulose composite and $200 \mathrm{mg}$ of CCFs were suspended in $200 \mathrm{~mL}$ of water using a mechanical homogenizer (IKA T25 Ultra-Turrax, Germany) at $6200 \mathrm{rpm}$ for $10 \mathrm{~min}$. The mixture was drained on a polypropylene filter and then dried to form a PPy/cellulose-CCFs paper sheet. As-prepared paper was heated to $1000{ }^{\circ} \mathrm{C}$ at a heating rate of $3{ }^{\circ} \mathrm{C} / \mathrm{min}$ and kept for $1 \mathrm{~h}$ under a nitrogen atmosphere to form the NCPE. The schematic illustrating of the synthetic procedure of the NCPE is shown in Scheme 1. The obtained NCPE was then punched into a disc with a diameter of $1.2 \mathrm{~cm}$ for directly using as an $\mathrm{O}_{2}$ electrode (Figure $\mathrm{S} 1 \mathrm{a}$ in Supplementary Information (SI)). In addition, in order to investigate the influence of the doping $\mathrm{N}$ on the $\mathrm{Li}-\mathrm{O}_{2}$ battery performance, a reference precursor of cellulose-CCFs paper sheet was also prepared under the similar conditions without the addition of PPy. Thus an undoped carbon paper electrode was obtained after annealing. 


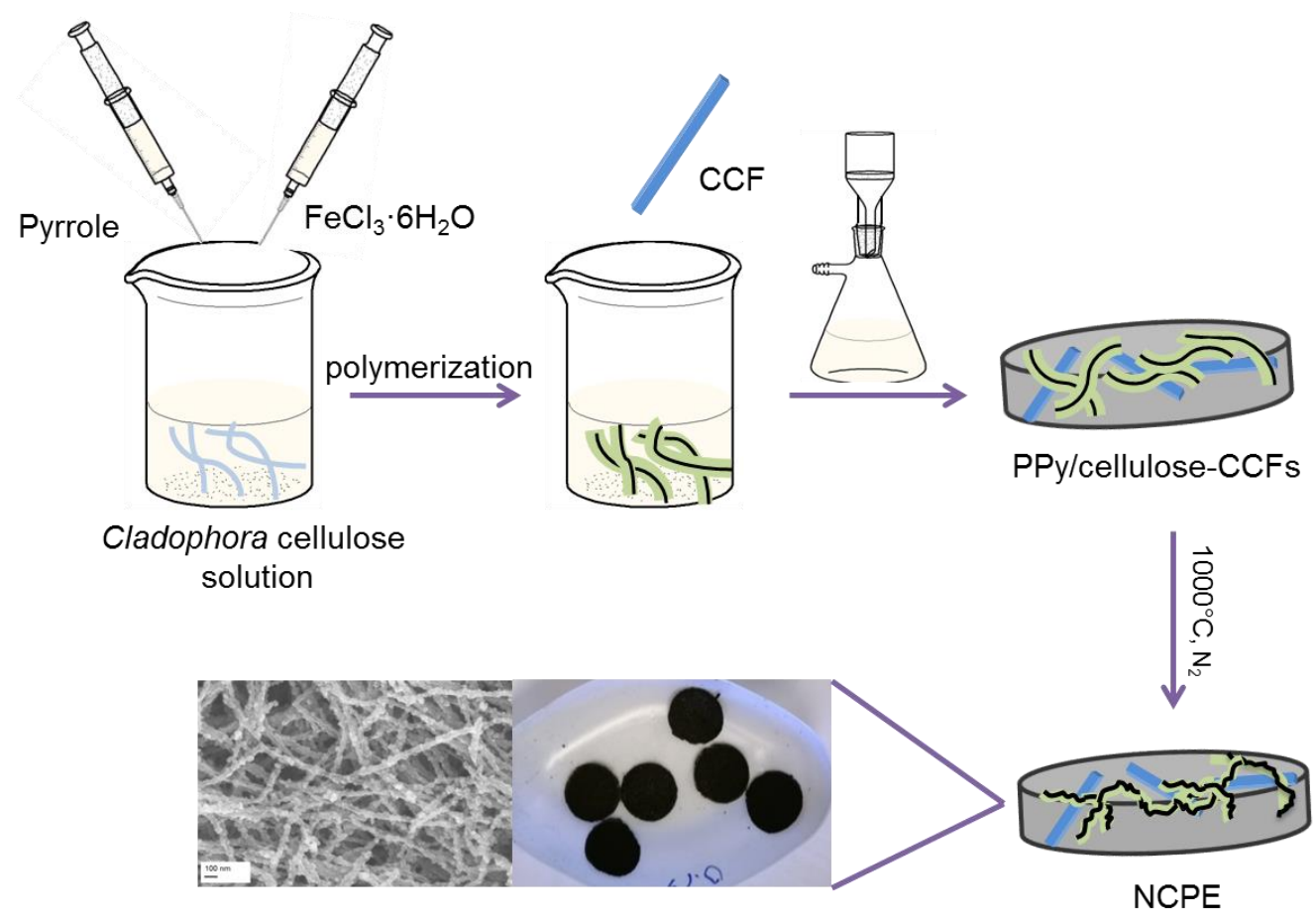

Scheme 1. Schematic illustrating of the synthetic procedure of the NCPE.

\subsection{Preparation of a reference electrode based on the chopped NCPE powder and binder}

In order to study the effect of binder-free architecture on the $\mathrm{Li}-\mathrm{O}_{2}$ battery performance, the NCPE was chopped into powder and mixed with binder to prepare a reference electrode. The chopped NCPE powder and Kynar 2801 (a copolymer based on PVdF, Arkema) were mixed with acetone solvent ( $\geq 99.0 \%$, Fluka) in a weight ratio of $90: 10$ by the high energy ballmilling for $1 \mathrm{~h}$ to prepare a slurry. This slurry was then cast drop-wise onto an aluminum mesh substrate with a diameter of $1.2 \mathrm{~cm}$. After acetone evaporation, an electrode based on the chopped NCPE powder and binder was obtained.

\subsection{Assembly of $\mathrm{Li}-\mathrm{O}_{2}$ battery and electrochemical testing}

As-prepared NCPE and the electrode made of chopped NCPE powder and binder were transferred to a vacuum furnace (Buchi Glass Oven B-585) in an Ar-filled glove box $\left(\mathrm{H}_{2} \mathrm{O}\right.$ and $\mathrm{O}_{2}<1 \mathrm{ppm}$ ), and dried at $120{ }^{\circ} \mathrm{C}$ overnight. The $\mathrm{Li}-\mathrm{O}_{2}$ batteries were assembled in a Swagelok design modified to allow pure and dry $\mathrm{O}_{2}$ to access through the electrode, which were set up in $\mathrm{O}_{2}$-filled bottles (Figures $\mathrm{S} 1 \mathrm{~b}$-d in SI). The $\mathrm{O}_{2}$ pressure inside the bottle during the battery operation was $1 \mathrm{~atm}$, and the volume of $\mathrm{O}_{2}$ was $300 \mathrm{~mL}$, which was 100 times more than the required amount for the discharge process. The components followed as: Li foil anode, double-layer Solupor separator presoaked in the electrolyte (1 $\left.\mathrm{M} \mathrm{LiClO}_{4} / \mathrm{DMSO}\right)$, and the NCPE or the chopped NCPE powder and binder-based cathode. The weight of each cathode was 4.5-6.5 mg. The electrochemical measurements were carried out using a Digatron BTS-600 battery system at galvanostatic current densities $\left(0.1 \mathrm{~mA} / \mathrm{cm}^{2}\right.$ (corresponding to $\sim 35 \mathrm{~mA} \mathrm{~g}^{-1}$ based on the N-doped carbon weight for the NCPE), 0.2, 0.4, and $0.8 \mathrm{~mA} / \mathrm{cm}^{2}$ ) within a potential range of $2.2-4.5 \mathrm{~V} v s . \mathrm{Li}^{+} / \mathrm{Li}$.

\subsection{Characterization}

The XRD analysis of NCPE was made by a Bruker D8 TwinTwin X-ray diffractometer (XRD), operating at $40 \mathrm{~mA}$ and $40 \mathrm{kV}$, using $\mathrm{Cu} \mathrm{K} \alpha$ radiation (wavelength $(\lambda)=1.5406 \AA$ ). The Raman spectrum was recorded on a RENISHAW inVia Raman Microscrope at room temperature, with an excitation laser wavelength $(\lambda)$ of $633 \mathrm{~nm}$. The BET surface area and 
porosity were determined by a nitrogen adsorption apparatus (Micromeritics ASAP 2020). Thermogravimetry (TG) measurement was performed on a TGA Q500 thermogravimetric analyzer from room temperature to $1000{ }^{\circ} \mathrm{C}$ at a heating rate of $10^{\circ} \mathrm{C} / \mathrm{min}$ under the $\mathrm{N}_{2}$ flow to study the pyrolysis process of the prepared PPy/cellulose and PPy/cellulose-CCFs. The morphology, particle size and element analysis were carried out by a scanning electron microscopy coupled with an energy dispersive spectroscopy (SEM/EDS-Zeiss 1550 with Aztec EDS). X-ray photoelectron spectroscopy (XPS) measurement was performed by a Perkin Elmer PHI 5500 spectrometer, using monochromatized Al K $\alpha$ radiation (hv = 1486.7 $\mathrm{eV}$ ) and an emission angle of $45^{\circ}$.

3. Results and discussion
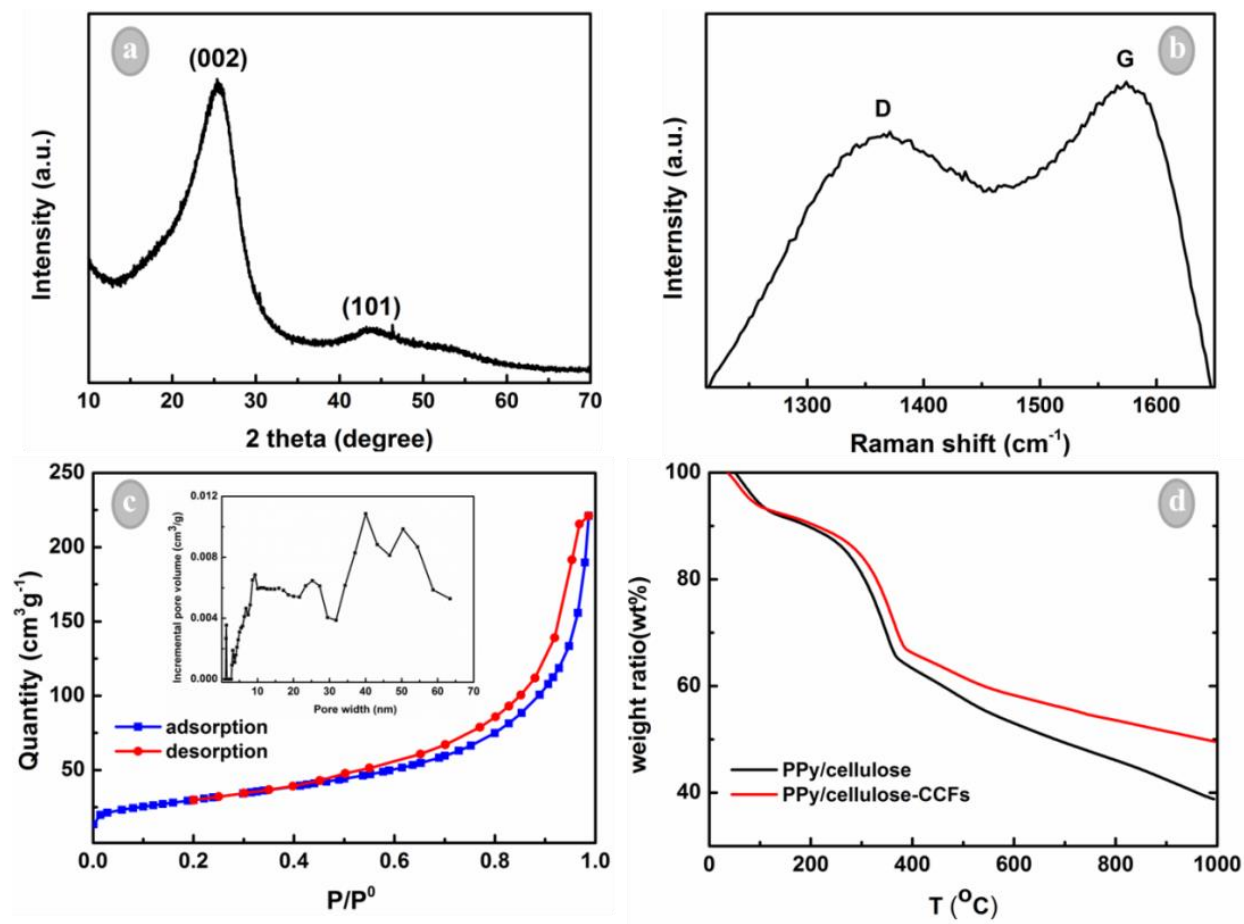

Figure 1. (a) XRD pattern, (b) Raman spectrum, (c) $\mathrm{N}_{2}$ adsorption/desorption isotherm curves (Inset: the pore size distribution) of the NCPE, and (d) TG curves of PPy/cellulose and PPy/cellulose-CCFs samples.

The XRD pattern of the NCPE is shown in Figure 1a. The diffraction peaks at $2 \theta=25.5^{\circ}$ and $42.7^{\circ}$ are indexed to the (002) and (101) reflections of graphitic carbon (JCPDS No. 00-0230064), respectively [35]. Note that the XRD pattern of the N-doped carbon obtained via a pyrolysis process of PPy/cellulose precursor showed the similar result (Figure S2 in SI), indicating that the diffraction peaks in Figure 1a mainly correspond to the N-doped carbon in NCPE instead of the CCFs. Figure 1b shows the Raman spectrum of the NCPE. The band at $1373 \mathrm{~cm}^{-1}$ (D-band) originates from defect-induced mode [19], while the band at $1575 \mathrm{~cm}^{-1}$ (G-band) corresponds to well-graphitized carbon [21], which agrees well with the XRD result. Figure 1c shows the $\mathrm{N}_{2}$ adsorption/desorption isotherm curves for the NCPE, which display the mesoporous structure (type IV shape) and which yield a surface area of $107 \mathrm{~m}^{2} \cdot \mathrm{g}^{-1}$. The NCPE has a pore size distribution in the range of 1-65 nm (Inset of Figure 1c). TG analysis not only characterizes the pyrolytic treatment, but also provides a feasible means for the quantitative analysis of the NCPE components. The NCPE was prepared by a simple carbonization of a PPy/cellulose-CCFs composite, during which process CCFs kept the same weight. In order to quantify the content of $\mathrm{N}$-doped carbon obtained after the pyrolysis of the $\mathrm{PPy} /$ cellulose precursor, the PPy/cellulose (without CCFs) was also prepared under the similar conditions. Figure 1d shows the TG curves of PPy/cellulose and PPy/cellulose-CCFs 
samples. Note that the weight changes of the PPy/cellulose and PPy/cellulose-CCFs samples have similar trends and the pyrolytic process of a $\mathrm{N}$-rich polymer composite can be divided into three steps, which is in good agreement with the literature [36]. Step I (35-120 $\left.{ }^{\circ} \mathrm{C}\right)$ corresponds to the loss of residual water in the samples. Step II $\left(120-380{ }^{\circ} \mathrm{C}\right)$ is assigned to the loss of volatile components, accompanied by the C-O bond cracking [37]. Step III (380$1000{ }^{\circ} \mathrm{C}$ ) is the carbonization period, connecting with the $\mathrm{C}-\mathrm{H}$ bond breaking [38]. There are $64 \mathrm{wt} \%$ of N-doped carbon and $36 \mathrm{wt} \%$ of CCFs in the NCPE, based on the TG results (the estimation follows the equations S1-S4 in SI).
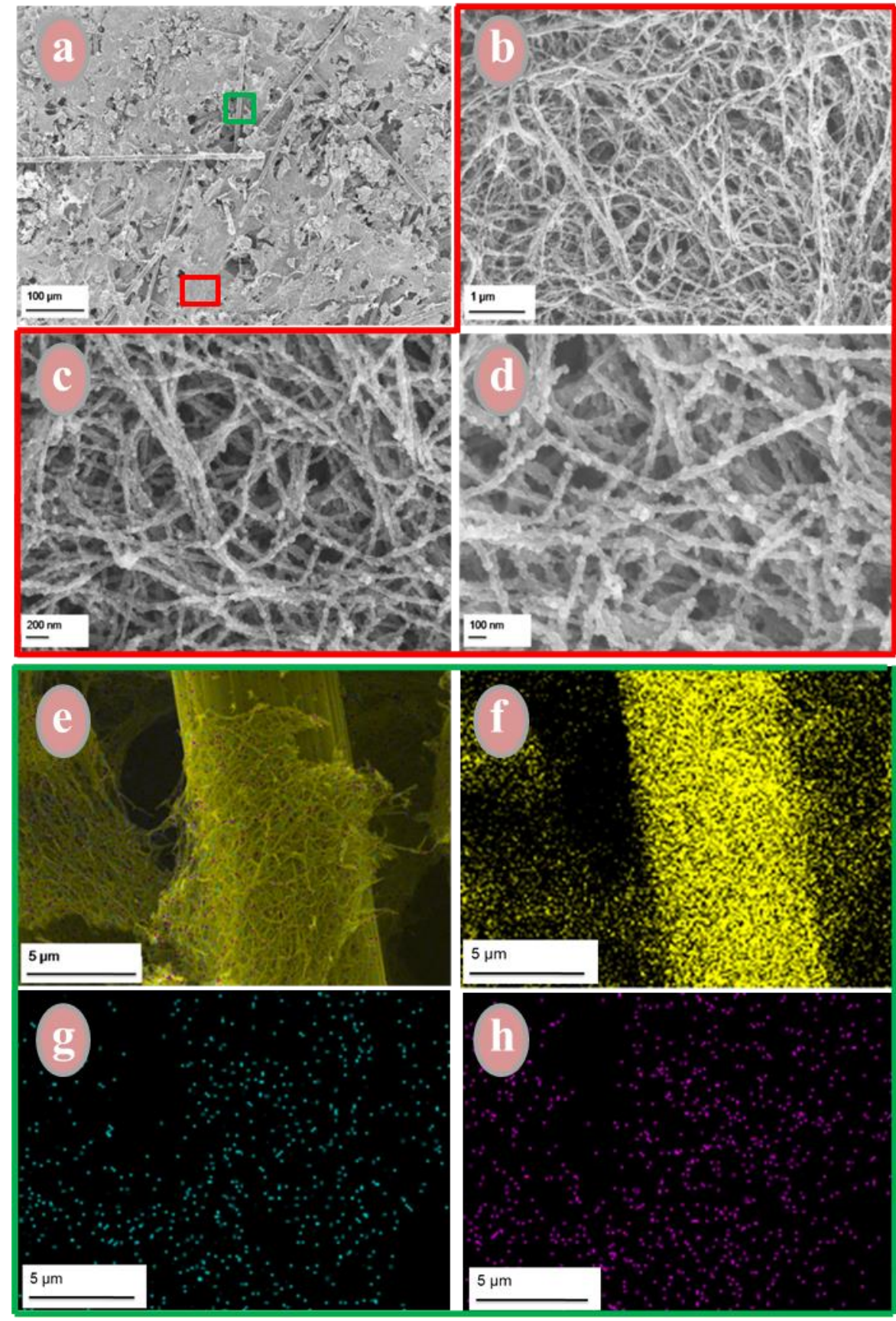

Figure 2. (a) SEM image of the NCPE, (b-d) SEM images of the region enclosed by the red frame in (a), (e) SEM image of the region enclosed by the green frame in (a), EDS elemental mapping of (f) $\mathrm{C},(\mathrm{g}) \mathrm{N}$, and (h) $\mathrm{O}$ in the SEM image (e).

The employment of CCFs can not only provide considerable conductivity and mechanical strength for the NCPE, but also support the self-standing electrode as a skeleton. Note that the 
sample without CCFs was very fragile. Figure 2 presents SEM images of the NCPE and the corresponding EDS elemental mapping of $\mathrm{C}, \mathrm{N}$, and $\mathrm{O}$. As depicted in Figure 2a, the CCFs, which show an average length of $1 \mathrm{~mm}$, are embedded in the NCPE. The morphology and size of CCF were not changed during the annealing (see Figure S3 in SI). During synthesis, the cellulose in the PPy/cellulose-CCFs composite acted as a structural and substrate template for the PPy coating [33]. Then, the N-doped carbon in the NCPE was obtained via a pyrolytic treatment of PPy/cellulose composite precursor. The N-doped carbon in the NCPE exhibited a bird's nest microstructure consisting of branches with a width of $\sim 70 \mathrm{~nm}$ (Figures $2 \mathrm{~b}-\mathrm{d}$ ). The branch surface was very rough, due to the pyrolysis treatment of the PPy [39]. This bird's nest architecture with stable integrity can provide the self-standing cathode with mechanic durability, fast $\mathrm{O}_{2}$ diffusion, and enough space for discharge product deposition, as wellstudied by previous reports $[18,40]$. As presented in Figure 2e, CCFs show the smooth surface with a diameter of $\sim 7 \mu \mathrm{m}$. The N-doped carbon seems firmly attached to the CCFs. From the EDS elemental mapping, the CCFs mainly consist of the $\mathrm{C}$ element (Figure 2f), while the $\mathrm{N}$-doped carbon is composed of well-dispersed $\mathrm{C}, \mathrm{N}$ and $\mathrm{O}$ elements (Figures 2f-2g), indicating that doping $\mathrm{N}$ via the pyrolysis of a $\mathrm{N}$-rich polymer composite was successful.
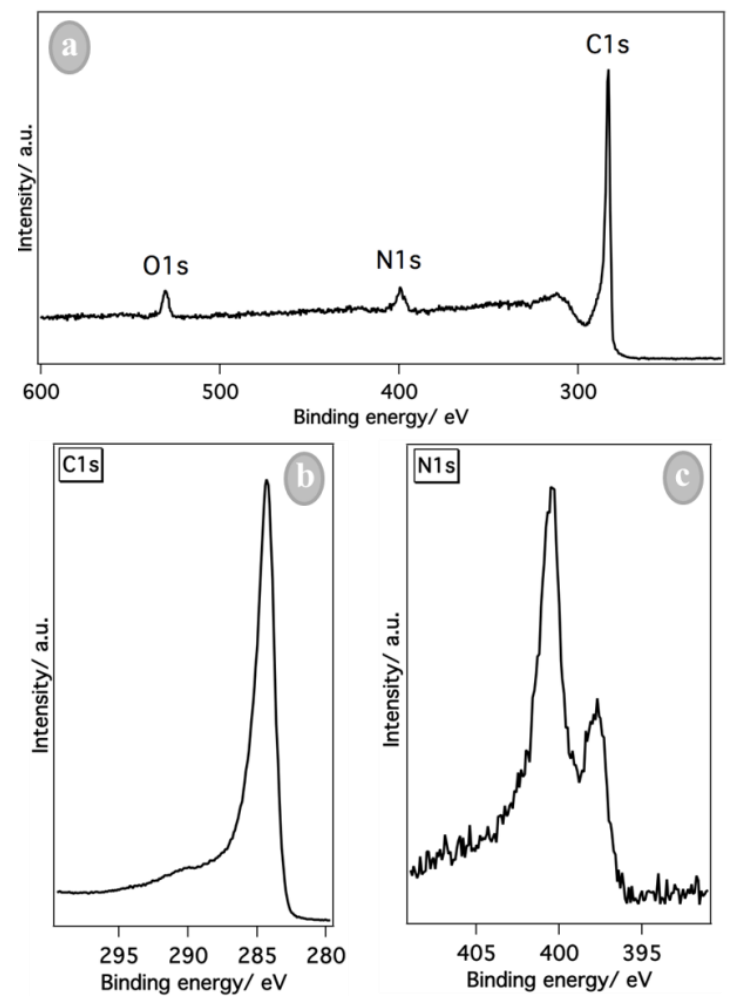

Figure 3. (a) XPS survey spectrum, (b) C1s and (c) N1s core level spectra of the NCPE.

The chemical states and surface compositions of the NCPE were studied by XPS. Figure 3a displays the survey spectrum $(0-600 \mathrm{eV})$ of the NCPE, which basically includes $\mathrm{C}, \mathrm{N}$, and $\mathrm{O}$ without any other impurities. The amount of doped N for the NCPE was $\sim 7 \mathrm{wt} \%$, based on the XPS results. The N1s spectrum for the NCPE contained two peaks at 397.7 and $400.4 \mathrm{eV}$, as shown in Figure 3c, which were in good agreement with the binding energies of the pyridinic and pyrrolic $\mathrm{N}[22,41]$, respectively. Therefore, it is evident that nitrogen atoms were doped into the carbon lattice instead of dangling on the carbon surface. The PPy consists of five-membered pyrrole rings, which can be partly converted to six-membered pyridine rings during pyrolysis. These $\mathrm{N}$-containing groups introduce the high positive spin density and asymmetry atomic charge density, resulting in the formation of defects and/or vacancies, which can promote the electrochemical reactions [17, 42-45]. 
a)

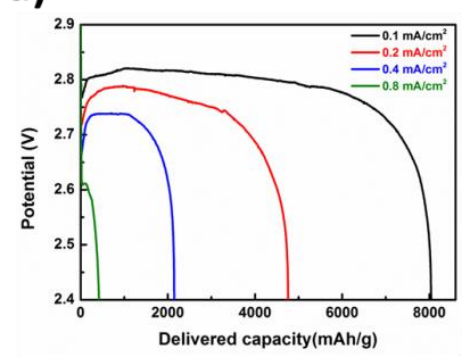

d)

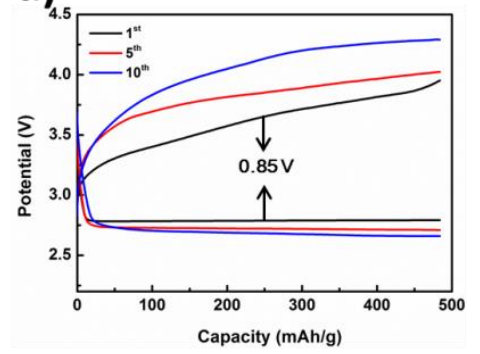

b)

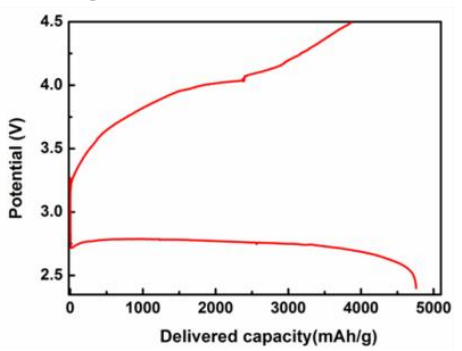

e)

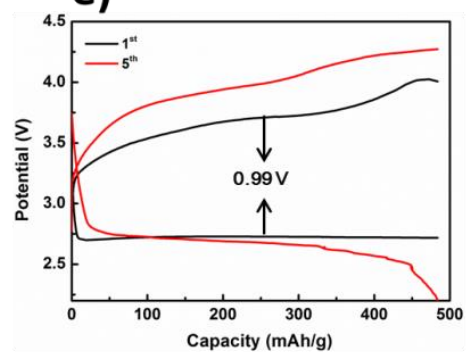

c)
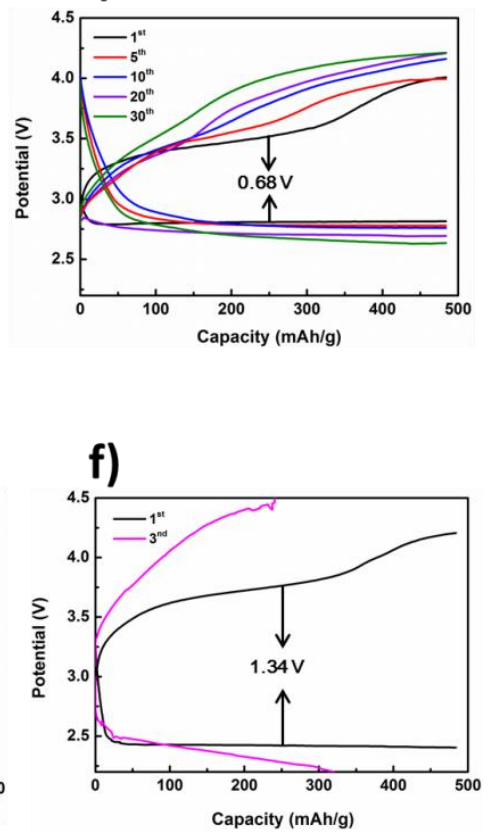

Figure 4. (a) The discharge profiles for $\mathrm{Li}-\mathrm{O}_{2}$ batteries with NCPEs at various current densities of $0.1,0.2,0.4$ and $0.8 \mathrm{~mA} / \mathrm{cm}^{2}$ with a cut off voltage of $2.4 \mathrm{~V}$, (b) discharge/charge profiles on the $1^{\text {st }}$ cycle for a $\mathrm{Li}-\mathrm{O}_{2}$ battery with the NCPE at a current density of $0.2 \mathrm{~mA} / \mathrm{cm}^{2}$ within a potential range of $2.4-4.5 \mathrm{~V} v s . \mathrm{Li}^{+} / \mathrm{Li}$, and the cycling response of the $\mathrm{Li}^{-} \mathrm{O}_{2}$ batteries with NCPEs at constant current densities of (c) 0.1 , (d) 0.2 , (e) $0.4 \mathrm{~mA} / \mathrm{cm}^{2}$, and (f) cycling response of a $\mathrm{Li}-\mathrm{O}_{2}$ battery with a reference electrode based on the chopped NCPE powder and binder at a constant current density of $0.2 \mathrm{~mA} / \mathrm{cm}^{2}$ under a specific capacity limit of 480 $\mathrm{mAh} \cdot \mathrm{g}^{-1}$ (based on the weight of $\mathrm{N}$-doped carbon) within a potential range of 2.2-4.5 $\mathrm{V} v s$. $\mathrm{Li}^{+} / \mathrm{Li}$.

The capacities were calculated based on the weight of the N-doped carbon in the NCPE, since the capacity of a reference cell excluding PPy could be neglected (see Figure S4 in SI), meaning that CCFs do not contribute to any capacity. The discharge profiles of $\mathrm{Li}-\mathrm{O}_{2}$ batteries with NCPEs at different current densities ranging from 0.1 to $0.8 \mathrm{~mA} / \mathrm{cm}^{2}$ are shown in Figure 4a. It can be seen that the $1^{\text {st }}$ discharge capacity of a cell at a current density of 0.1 $\mathrm{mA} / \mathrm{cm}^{2}$ reached $8040 \mathrm{mAh} \cdot \mathrm{g}^{-1}$. The achieved capacity and operating potential decreased with increasing current density. When higher current densities of $0.2,0.4$ and $0.8 \mathrm{~mA} / \mathrm{cm}^{2}$ were used, the $1^{\text {st }}$ discharge capacities were 4759,2147 , and $419 \mathrm{mAh} \cdot \mathrm{g}^{-1}$, respectively. The specific area resistance of the NCPE was around $267 \Omega \cdot \mathrm{cm}^{2}$ (the estimation follows the equation S5 in SI). The galvanostatic discharge/charge curves on the $1^{\text {st }}$ cycle for a $\mathrm{Li}-\mathrm{O}_{2}$ battery at a current density of $0.2 \mathrm{~mA} / \mathrm{cm}^{2}$ is shown in Figure $4 \mathrm{~b}$. The discharge and charge capacities were 4759 and $3865 \mathrm{mAh} \cdot \mathrm{g}^{-1}$ respectively, indicating that this cell exhibited a coulombic efficiency of $81 \%$. The cyclability and rate performance of $\mathrm{Li}^{-} \mathrm{O}_{2}$ batteries with NCPEs under a capacity limit of $480 \mathrm{mAh} \cdot \mathrm{g}^{-1}$ at various current densities $\left(0.1-0.4 \mathrm{~mA} / \mathrm{cm}^{2}\right)$ were evaluated via time-controlled and voltage-controlled modes. As shown in Figure 4c, a Li- $\mathrm{O}_{2}$ cell with the NCPE presented a cyclability of more than 30 cycles at a current density of $0.1 \mathrm{~mA} / \mathrm{cm}^{2}$. Note that there were two potential stages during the charge process. The first could be assigned to the $\mathrm{Li}_{2} \mathrm{O}_{2}$ oxidation, while the other may correspond to electrolyte decomposition [46, 47], and/or the $\mathrm{LiOH}$ oxidation [5]. $\mathrm{LiOH}$ could be formed due to the introduction of water into the system via the DMSO solvent, and/or the DMSO oxidation by reactive oxygen species (e.g., $\mathrm{LiO}_{2}$ and $\mathrm{Li}_{2} \mathrm{O}_{2}$ ) [48, 49]. The overpotentials increased gradually with the cycle number, mainly due to the increased charge potentials. In addition, the discharge capacity dropped after 30 cycles (Figure S5a in SI). Besides the fact that 
DMSO is not completely stable, the instability of contact interface between Li metal and DMSO could be another reason for the sudden death of the battery [50, 51] (see Figure S6 in SI). The batteries sustained 14 and 5 cycles with a capacity limit of $480 \mathrm{mAh} \cdot \mathrm{g}^{-1}$ at constant current densities of 0.2 and $0.4 \mathrm{~mA} / \mathrm{cm}^{2}$, respectively (Figures S5b and $5 \mathrm{c}$ in SI). The cell overpotential on the $1^{\text {st }}$ cycle increased from 0.68 to $0.99 \mathrm{~V}$, when raising the current density from 0.1 to $0.4 \mathrm{~mA} / \mathrm{cm}^{2}$ (Figures $4 \mathrm{c}-\mathrm{e}$ ).

In order to know how the unique architecture of the NCPE benefits the battery performance, the cycling response of a $\mathrm{Li}_{-} \mathrm{O}_{2}$ battery with a reference electrode based on chopped NCPE powder and binder was studied, as shown in Figure 4f. It can be seen that the cell overpotential $(1.34 \mathrm{~V})$ on the $1^{\text {st }}$ cycle was much higher than that $(0.85 \mathrm{~V})$ for a cell with the NCPE. Additionally, the battery only sustained 2 cycles with a capacity limit of $480 \mathrm{mAh} \cdot \mathrm{g}^{-1}$, and there was an obvious capacity loss on the following $3^{\text {rd }}$ cycle. There can be two possible reasons for this poor cyclability. One is that an aggregation of electrode materials due to the binder addition impeded the $\mathrm{O}_{2}$ diffusion and limited the $\mathrm{Li}_{2} \mathrm{O}_{2}$ deposition space, which was supported by the SEM image of this binder-containing electrode (Figure S7 in SI). The other may be that the binder-involved side reactions interfered with the electrochemical processes [52]. This experiment confirms the advantages of bird nest's structure and binder-free design.

Since pyrrole is the $\mathrm{N}$ precursor in this work, the only way to study the $\mathrm{N}$-doping effect is to exclude pyrrole (i.e., without the formation of PPy before carbonization) in the synthesis. The cell with the electrode excluding PPy showed very low capacity (Figure S4 in SI), indicating that $\mathrm{N}$ groups and other components formed via the carbonization of PPy are important functional materials for $\mathrm{Li}-\mathrm{O}_{2}$ battery.

\section{Conclusion}

The fabrication of NCPE can be considered as a green chemistry process, since it uses cheap raw materials (e.g., Cladophora sp. green algae) and involves easy operations (e.g., doping $\mathrm{N}$ via the pyrolysis of a N-rich polymer composite). The NCPE displays a bird's nest microstructure, which could provide the self-standing electrode with mechanic durability, fast $\mathrm{O}_{2}$ diffusion, and enough space for discharge product deposition. The $\mathrm{N}$-doped carbon in the NCPE provided the N-containing function groups, which can promote the electrochemical reactions. The $1^{\text {st }}$ discharge capacity for a $\mathrm{Li}-\mathrm{O}_{2}$ cell with the NCPE at the current density of $0.1 \mathrm{~mA} / \mathrm{cm}^{2}$ reached $8040 \mathrm{mAh} \cdot \mathrm{g}^{-1}$ with a cell voltage around $2.81 \mathrm{~V}$. In addition, the cell with the NCPE presented a cyclability of more than 30 cycles at a constant current density of $0.1 \mathrm{~mA} / \mathrm{cm}^{2}$. It exhibited a coulombic efficiency of $81 \%$ on the $1^{\text {st }}$ cycle at the current density of $0.2 \mathrm{~mA} / \mathrm{cm}^{2}$. We think that this new designed NCPE can make a contribution to improving the energy density (without metal and binder) and preventing some parasitic reactions (e.g., from binder degradation) for $\mathrm{Li}_{-} \mathrm{O}_{2}$ batteries.

\section{Acknowledgements}

This work is supported by Swedish Research Council, Swedish Energy Agency, Ångpanneföreningen's Foundation for Research and Development, J. Gust. Richert Foundation, the State Key Laboratory of Fine Chemicals (KF1413) and China Scholarship Council.

Reference:

[1] H. Wang, Y. Yang, Y. Liang, G. Zheng, Y. Li, Y. Cui, H. Dai, Energy \& Environmental Science, 5 (2012) 7931-7935. 
[2] J. Liu, M. Roberts, R. Younesi, M. Dahbi, K. Edström, T. Gustafsson, J. Zhu, The Journal of Physical Chemistry Letters, 4 (2013) 4045-4050.

[3] R. Younesi, M. Hahlin, K. Edström, ACS applied materials \& interfaces, 5 (2013) 1333-1341.

[4] D. Sun, Y. Shen, W. Zhang, L. Yu, Z. Yi, W. Yin, D. Wang, Y. Huang, J. Wang, D. Wang, J.B. Goodenough, 136 (2014) 8941-8946.

[5] Y. Shen, D. Sun, L. Yu, W. Zhang, Y. Shang, H. Tang, J. Wu, A. Cao, Y. Huang, Carbon, 62 (2013) 288-295.

[6] Z. Jian, P. Liu, F. Li, P. He, X. Guo, M. Chen, H. Zhou, 53 (2014) 442-446.

[7] R. Younesi, S. Urbonaite, K. Edström, M. Hahlin, The Journal of Physical Chemistry C, 116 (2012) 20673-20680.

[8] Y. Shao, F. Ding, J. Xiao, J. Zhang, W. Xu, S. Park, J.-G. Zhang, Y. Wang, J. Liu, 23 (2013) 9871004.

[9] P. Trogadas, T.F. Fuller, P. Strasser, Carbon, 75 (2014) 5-42.

[10] M.M. Ottakam Thotiyl, S.A. Freunberger, Z. Peng, P.G. Bruce, J Am Chem Soc, 135 (2013) 494500 .

[11] R.E. Fuentes, H.R. Colón-Mercado, E.B. Fox, Journal of Power Sources, 255 (2014) 219-222.

[12] S.Y. Kim, H.T. Lee, K.B. Kim, Physical chemistry chemical physics : PCCP, 15 (2013) 2026220271.

[13] J. Kang, O.L. Li, N. Saito, 261 (2014) 156-161.

[14] S. Wang, X. Zhao, T. Cochell, A. Manthiram, The Journal of Physical Chemistry Letters, 3 (2012) 2164-2167.

[15] Y. Lu, Z. Wen, J. Jin, Y. Cui, M. Wu, S. Sun, Journal of Solid State Electrochemistry, 16 (2012) $1863-1868$.

[16] K. Zhang, L. Zhang, X. Chen, X. He, X. Wang, S. Dong, L. Gu, Z. Liu, C. Huang, G. Cui, ACS applied materials \& interfaces, 5 (2013) 3677-3682.

[17] L. Li, A. Manthiram, 4 (2014) 130175.

[18] X. Lin, X. Lu, T. Huang, Z. Liu, A. Yu, 242 (2013) 855-859.

[19] Z. Wang, X. Xiong, L. Qie, Y. Huang, Electrochimica Acta, 106 (2013) 320-326.

[20] H. Li, W. Kang, L. Wang, Q. Yue, S. Xu, H. Wang, J. Liu, Carbon, 54 (2013) 249-257.

[21] R. Mi, H. Liu, H. Wang, K.-W. Wong, J. Mei, Y. Chen, W.-M. Lau, H. Yan, Carbon, 67 (2014) 744-752.

[22] W.H. Shin, H.M. Jeong, B.G. Kim, J.K. Kang, J.W. Choi, Nano letters, 12 (2012) 2283-2288.

[23] Z. Wang, L. Qie, L. Yuan, W. Zhang, X. Hu, Y. Huang, Carbon, 55 (2013) 328-334.

[24] Z. Chen, A. Yu, D. Higgins, H. Li, H. Wang, Z. Chen, Nano letters, 12 (2012) 1946-1952.

[25] Z.-L. Wang, D. Xu, J.-J. Xu, L.-L. Zhang, X.-B. Zhang, 22 (2012) 3699-3705.

[26] R. Younesi, M. Hahlin, F. Björefors, P. Johansson, K. Edström, Chemistry of Materials, 25 (2013) 77-84.

[27] W. Zhang, J. Zhu, H. Ang, Y. Zeng, N. Xiao, Y. Gao, W. Liu, H.H. Hng, Q. Yan, Nanoscale, 5 (2013) 9651-9658.

[28] T. Cetinkaya, S. Ozcan, M. Uysal, M.O. Guler, H. Akbulut, Journal of Power Sources, 267 (2014) $140-147$.

[29] Z. Jian, Y. Chen, F. Li, T. Zhang, C. Liu, H. Zhou, Journal of Power Sources, 251 (2014) 466-469.

[30] Z. Wang, P. Tammela, P. Zhang, M. Strømme, L. Nyholm, Journal of Materials Chemistry A, 2 (2014) 16761-16769.

[31] Z. Wang, P. Tammela, P. Zhang, J. Huo, F. Ericson, M. Stromme, L. Nyholm, 6 (2014) 1306813075.

[32] L. Nyholm, G. Nyström, A. Mihranyan, M. Strømme, 23 (2011) 3751-3769.

[33] P. Tammela, Z. Wang, S. Frykstrand, P. Zhang, I.-M. Sintorn, L. Nyholm, M. Stromme, RSC Advances, 5 (2015) 16405-16413.

[34] A. Naseem, C.J. Olliff, L.G. Martini, A.W. Lloyd, International Journal of Pharmaceutics, 269 (2004) 443-450.

[35] T. Fu, R. Liu, J. Lv, Z. Li, Fuel Processing Technology, 122 (2014) 49-57.

[36] P. Veselá, V. Slovák, Journal of Thermal Analysis and Calorimetry, 113 (2013) 209-217.

[37] M. Reuß, L. Ratke, Journal of Sol-Gel Science and Technology, 47 (2008) 74-80.

[38] C. Lin, J.A. Ritter, Carbon, 35 (1997) 1271-1278.

[39] X. Yang, W. Zou, Y. Su, Y. Zhu, H. Jiang, J. Shen, C. Li, Journal of Power Sources, 266 (2014) 36-42.

[40] F. Li, Y. Chen, D.-M. Tang, Z. Jian, C. Liu, D. Golberg, A. Yamada, H. Zhou, Energy \& Environmental Science, 7 (2014) 1648. 
[41] W. Luo, B. Wang, C.G. Heron, M.J. Allen, J. Morre, C.S. Maier, W.F. Stickle, X. Ji, Nano letters, 14 (2014) 2225-2229.

[42] D. Yu, Q. Zhang, L. Dai, J. Am. Chem. Soc., 132 (2010) 15127-15129.

[43] H. Wang, T. Maiyalagan, X. Wang, ACS Catalysis, 2 (2012) 781-794.

[44] W. Liang, J. Chen, Y. Liu, S. Chen, ACS Catalysis, 4 (2014) 4170-4177.

[45] L. Zhang, J. Niu, L. Dai, Z. Xia, Langmuir, 28 (2012) 7542-7550.

[46] F. Li, T. Zhang, H. Zhou, Energy \& Environmental Science, 6 (2013) 1125-1141.

[47] M.M.O. Thotiyl, S.A. Freunberger, Z. Peng, Y. Chen, Zheng Liu, P.G. Bruce, Nature Materials, 12 (2013) 1051-1056.

[48] D. Sharon, M. Afri, M. Noked, A. Garsuch, A.A. Frimer, D. Aurbach, The Journal of physical chemistry letters, 4 (2013) 3115-3119.

[49] A.C. Luntz, B.D. McCloskey, Chemical Reviews, 114 (2014) 11721-11750.

[50] J. Liu, R. Younesi, T. Gustafsson, K. Edström, J. Zhu, Nano Energy, 10 (2014) 19-27.

[51] Z. Peng, S.A. Freunberger, Y. Chen, P.G. Bruce, Science, 337 (2012) 563-566.

[52] R. Younesi, M. Hahlin, M. Treskow, J. Scheers, P. Johansson, K. Edström, The Journal of Physical Chemistry C, 116 (2012) 18597-18604. 


\section{Supplementary Information}

\section{Binder-free nitrogen-doped carbon paper electrodes derived from polypyrrole/cellulose composite for $\mathrm{Li}-\mathrm{O}_{2}$ batteries}

Jia Liu, Zhaohui Wang, Reza Younesi, Leif Nyholm, Kristina Edström, and Jiefang Zhu* Department of Chemistry - Ångström Laboratory, Uppsala University, Box 538, SE-751 21

Uppsala, Sweden

Tel.: +4618 471 3722, Fax: +46 18513548, E-mail: jiefang.zhu@kemi.uu.se
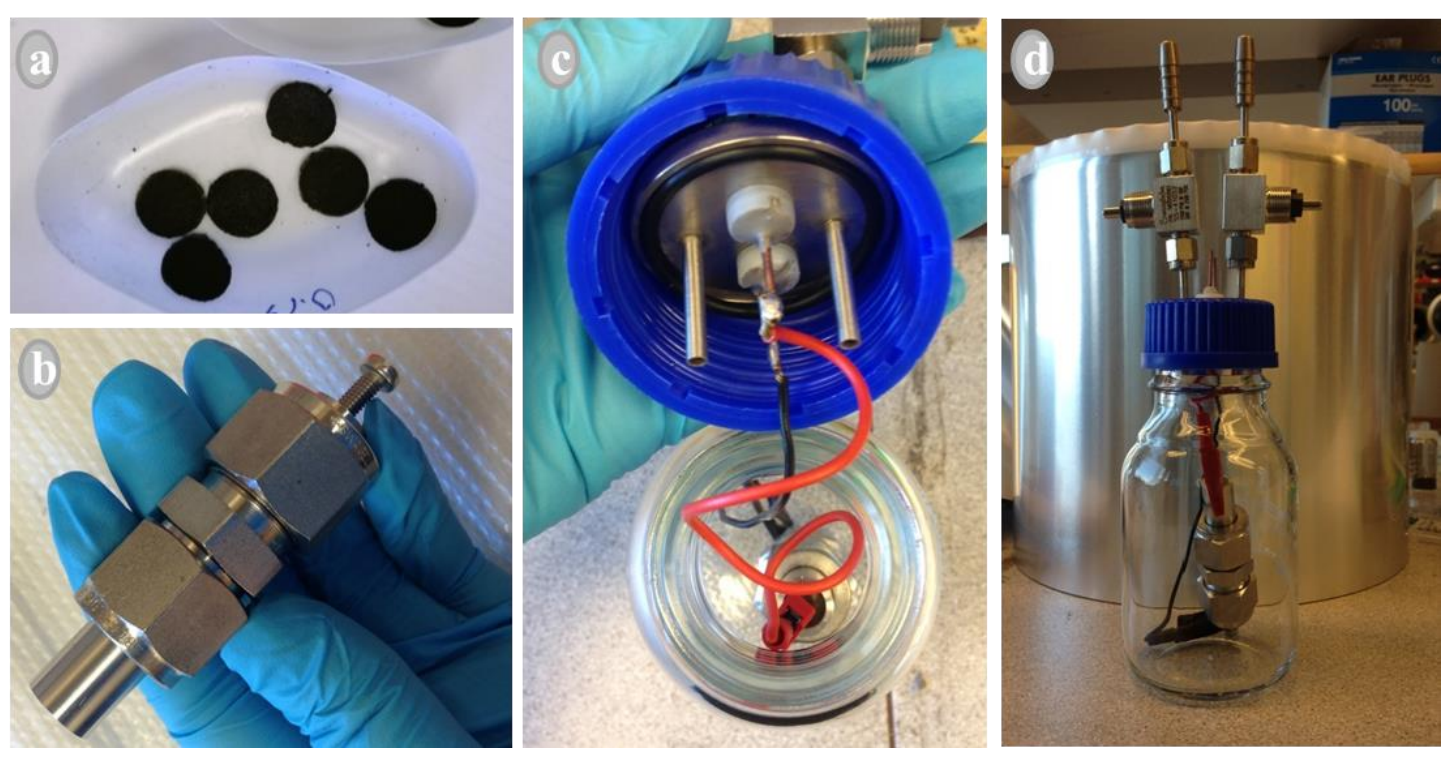

Figure S1. Images of (a) NCPEs, and a Swagelok design (b) modified with (c, d) an airtight container with inlet and outlet valves. 


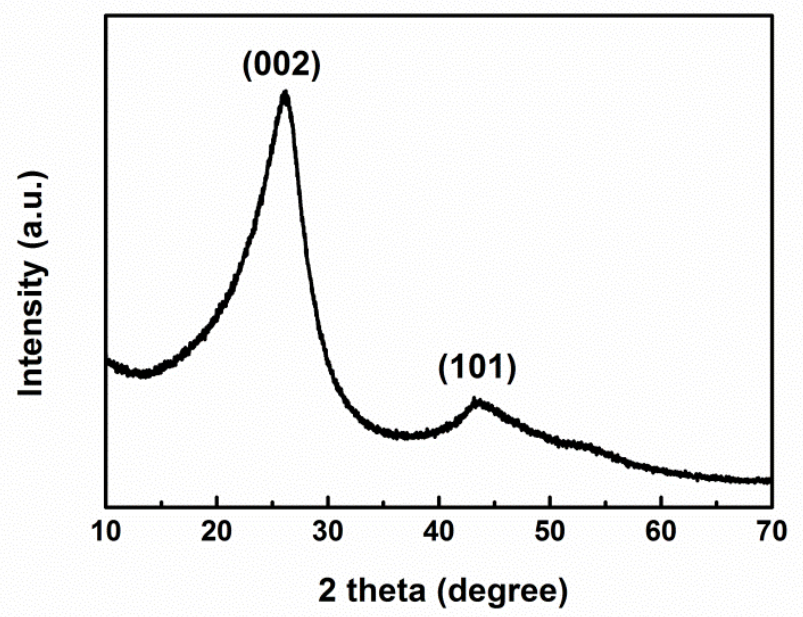

Figure S2. XRD pattern of N-doped carbon obtained by a pyrolysis process of PPy/cellulose precursor.

Figure $\mathrm{S} 2$ shows the XRD pattern of the N-doped carbon obtained via a pyrolysis process of PPy/cellulose precursor. The diffraction peaks at $2 \theta=25.5^{\circ}$ and $42.7^{\circ}$ correspond to the (002) and (101) planes of graphitic carbon, respectively.

The weight ratios of $\mathrm{N}$-doped carbon and CCFs in the NCPE were estimated from the following formulas, according to the TG results:

$\mathrm{x}_{1}+\mathrm{y}_{1}=100 \%$

$38.8 \% \cdot \mathrm{x}_{1}+\mathrm{y}_{1}=49.6 \%$

$\mathrm{x}_{2}=\left(38.8 \% \cdot \mathrm{x}_{1}\right) / 49.6$

$\mathrm{y}_{2}=\mathrm{y}_{1} / 49.6$

where $\mathrm{x}_{1}$ and $\mathrm{y}_{1}$ are the weight ratios of PPy/cellulose and CCFs in the PPy/cellulose-CCFs sample (before calcination), respectively; $\mathrm{x}_{2}$ and $\mathrm{y}_{2}$ are the weight ratios of $\mathrm{N}$-doped carbon and CCFs in the NCPE (after calcination), respectively. Before the calcination, there are PPy/cellulose and CCFs in the PPy/cellulose-CCFs sample $\left(\mathrm{x}_{1}+\mathrm{y}_{1}=100 \%\right)$. After the calcination, the CCFs weight $\left(\mathrm{y}_{1}\right)$ should not change, while the N-doped carbon is obtained from the PPy/cellulose $\left(38.8 \% \cdot \mathrm{x}_{1}\right)$, since the residual weight ratio is $38.8 \%$ for the PPy/cellulose sample (Figure 1d). Therefore, the total residual of PPy/cellulose-CCFs $(49.6 \%)$ after the calcination should be the sum of $\mathrm{y}_{1}$ and $38.8 \% \cdot \mathrm{x}_{1}$. From equations $\mathrm{S} 1$ and $\mathrm{S} 2, \mathrm{x}_{1}$ and $\mathrm{y}_{1}$ are equal to $82 \%$ and $18 \%$, respectively. After the calcination, the sum of $\mathrm{N}$ doped carbon and CCFs in NCPE sample is $49.6 \%$ as compared to PPy@cellulose-CCFs sample. Thus the weight ratios of $\mathrm{N}$-doped carbon and CCFs could be calculated from $\mathrm{x}_{2}=$ $\left(38.8 \% \cdot \mathrm{x}_{1}\right) / 49.6$ and $\mathrm{y}_{2}=\mathrm{y}_{1} / 49.6$, respectively. 

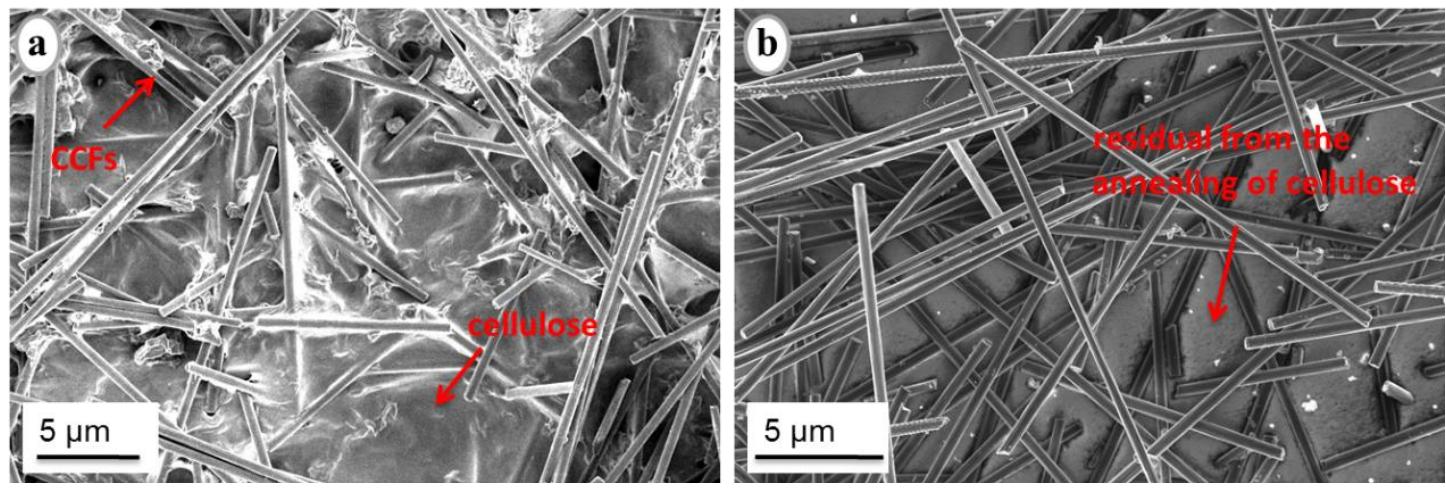

Figure S3. SEM images of (a) the cellulose-CCFs paper sheet, and (b) undoped carbon paper electrode obtained via the annealing of (a).

Figure S3 presents SEM images of the cellulose-CCFs paper sheet and the derivative undoped carbon paper electrode thereof. Note that the morphology and size of CCFs were not changed after the heat treatment.

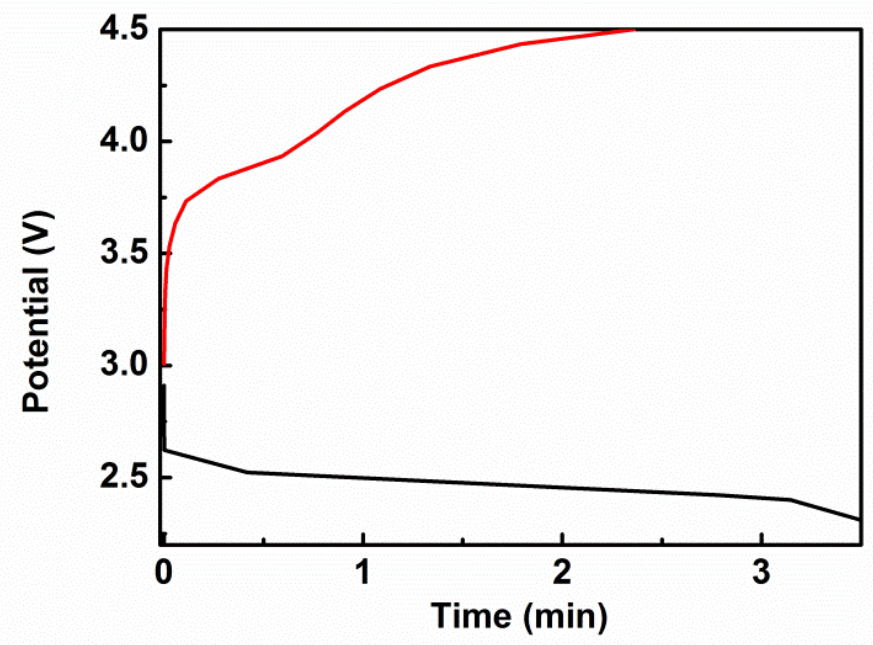

Figure S4. The discharge/charge profiles of a cell with an undoped carbon paper electrode at a current density of $0.2 \mathrm{~mA} / \mathrm{cm}^{2}$ within a potential range of $2.2-4.5 \mathrm{~V} v s . \mathrm{Li}^{+} / \mathrm{Li}$.

Figure S4 shows the discharge/charge profiles of a cell with an undoped carbon paper electrode at a current density of $0.2 \mathrm{~mA} / \mathrm{cm}^{2}$ within a potential range of $2.2-4.5 \mathrm{~V} v s . \mathrm{Li}^{+} / \mathrm{Li}$. Compared to the discharge capacity $\left(4759 \mathrm{mAh}^{-1}\right)$ of a cell with the NCPE running at the same current density, the discharge capacity of this cell could be neglected (the discharge process only took $\sim 3.5 \mathrm{~min}$ ). This provides an evidence that the $\mathrm{N}$-doped carbon is the functional material that contributes to battery capacity, and $\mathrm{N}$-containing function groups can promote the electrochemical reactions.

$\mathrm{R}=\Delta \mathrm{E}_{\text {discharge }} / \Delta \mathrm{I}=\left(\mathrm{E}_{1}-\mathrm{E}_{2}\right) /\left(\mathrm{I}_{2}-\mathrm{I}_{1}\right)=(2.81-2.73) \times 1000 /(0.4-0.1)=267 \Omega \cdot \mathrm{cm}^{2}$

where $\mathrm{R}\left(\Omega \cdot \mathrm{cm}^{2}\right), \Delta \mathrm{E}_{\text {discharge }}(\mathrm{V})$, and $\Delta \mathrm{I}\left(\mathrm{A} / \mathrm{cm}^{2}\right)$ represent the specific area resistance, discharge potential difference, and current density difference, respectively. $E_{1}$ and $E_{2}$ are the cell voltages corresponding to the batteries discharging at current densities of 0.1 and 0.4 
$\mathrm{mA} / \mathrm{cm}^{2}$, respectively, while $I_{1}$ and $I_{2}$ are the current densities of 0.1 and $0.4 \mathrm{~mA} / \mathrm{cm}^{2}$, respectively.
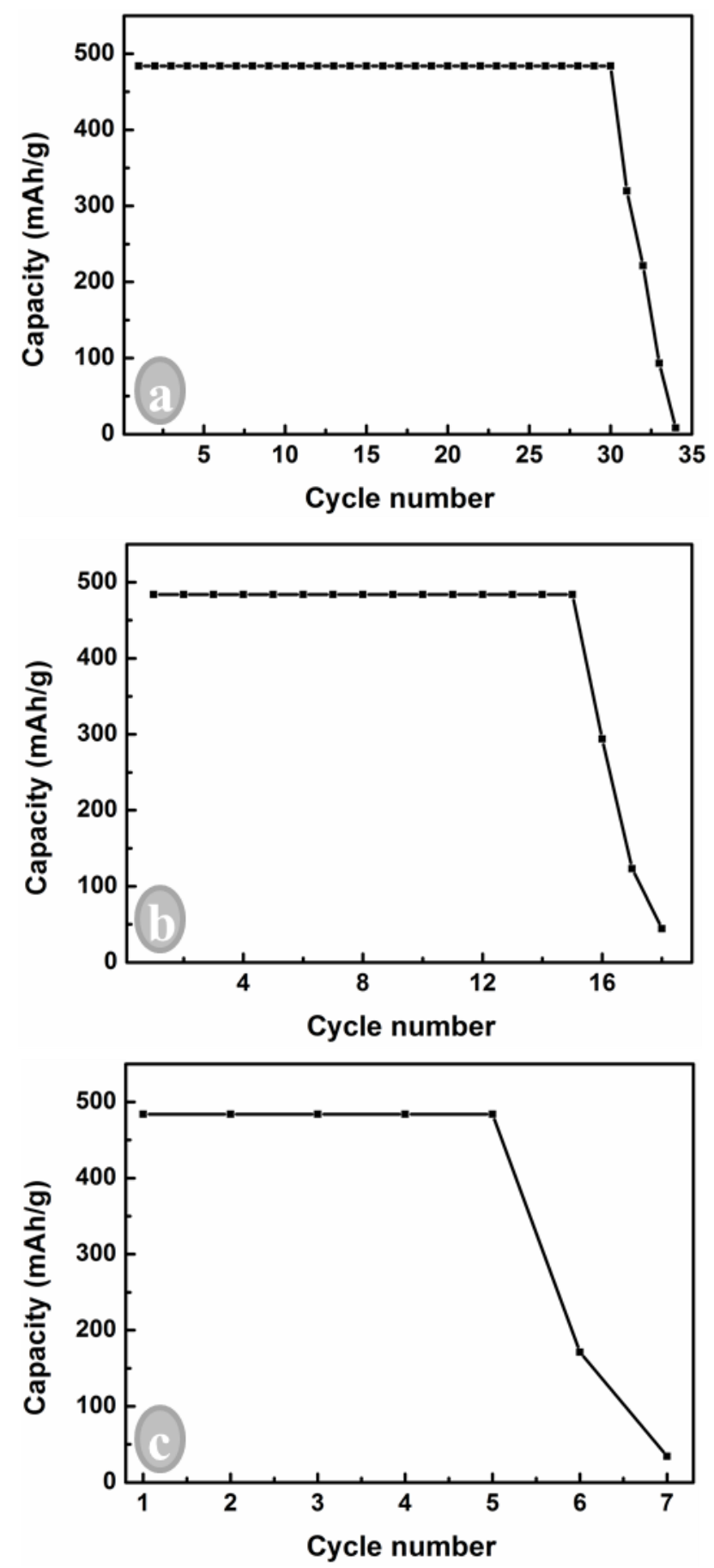

Figure S5. Discharge capacity $v s$. cycle number for the batteries with NCPEs cycled at current densities of (a) 0.1 , (b) 0.2 , and (c) $0.4 \mathrm{~mA} / \mathrm{cm}^{2}$. 


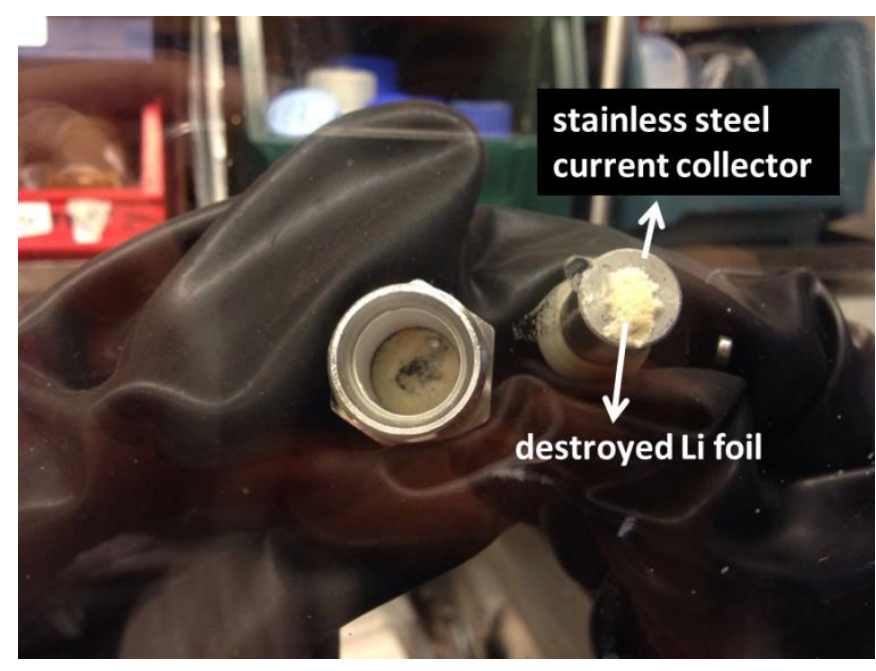

Figure S6. Image of destroyed $\mathrm{Li}$ foil for a $\mathrm{Li}-\mathrm{O}_{2}$ battery after 30 cycles under a specific capacity limit of $480 \mathrm{mAh} \cdot \mathrm{g}^{-1}$ at a constant current density of $0.1 \mathrm{~mA} / \mathrm{cm}^{2}$.

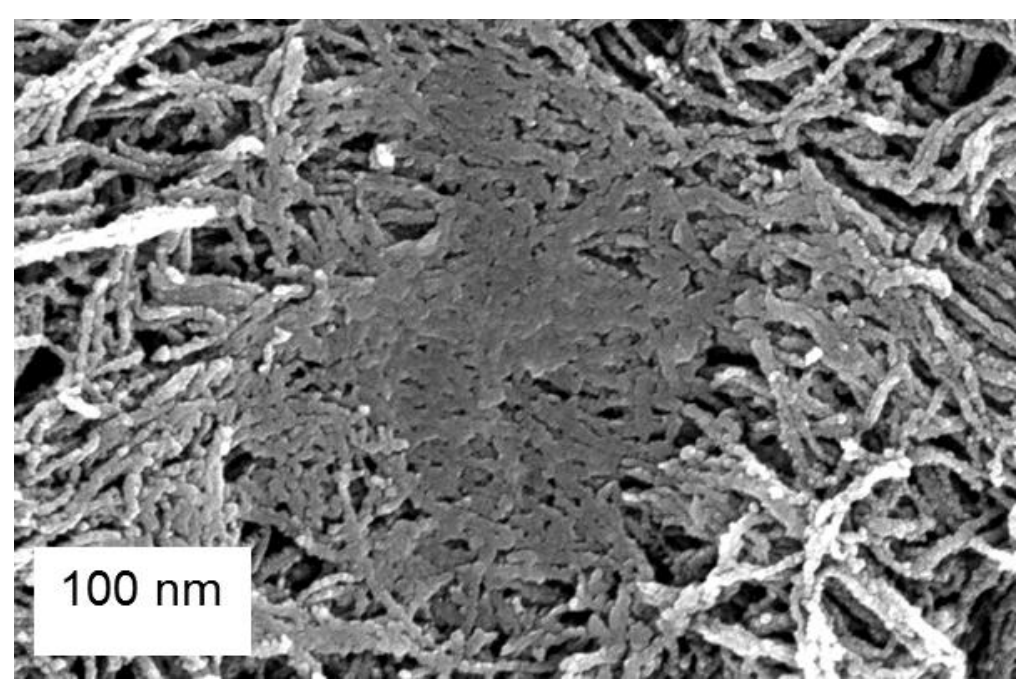

Figure S7. SEM image of an electrode based on chopped NCPE powder and binder.

The SEM image of a reference electrode based on chopped NCPE powder and binder is shown in Figure S7. It can be seen that there was an obvious aggregation of the $\mathrm{N}$-doped carbon, due to the binder addition. 